\title{
Biodegradation of Dimethyl Phthalate, Diethyl Phthalate, Dibutyl Phthalate and Their Mixture by Variovorax Sp.
}

\author{
B. Prasad and S. Suresh
}

\begin{abstract}
Biodegradation of dimethyl phthalate (DMP), diethyl phthalate (DEP) and dibutyl phthalate (DBP) and their mixture by a bacterial strain is reported. The strain was isolated by enrichment technique from garbage dumped soil nearby Indian Institute of Technology Bombay. The isolate had the ability to utilize mixture of DMP, DEP and DBP in the growth medium as well as the individual phthalate esters as the sole source of carbon and energy. The bacterial isolate was identified as Variovorax sp. based on 16S r-DNA sequence analysis. Variovorax sp. degraded $>99 \%$ of $300 \mathrm{mg} / \mathrm{l}$ of DMP, DEP, DBP or a mixture containing $100 \mathrm{mg} / \mathrm{l}$ of each within $30 \mathrm{~h}$. Metabolites or end products were not detected by HPLC analyses. Biodegradation of phthalate esters followed first-order kinetics. The rates of biodegradation of individual esters followed the order: $D E P>D B P>D M P$ while in the mixture, rates followed the order: $D E P>D M P>D B P$. Crude cell free extracts prepared from bacterial isolates contained cocktail of inducible enzymes responsible for the degradation of DMP or DEP.
\end{abstract}

Index Terms-Biodegradation, enzyme, phthalate esters, variovorax.

\section{INTRODUCTION}

Phthalate esters (PAEs) are a group of compounds, which include dialkyl or alkyl aryl esters of 1, 2 -benzendicarboxylic acid (phthalic acid). Among phthalates esters, dimethyl phthalate (DMP), diethyl phthalate (DEP) and dibutyl phthalate (DBP) are mostly used for a variety of commercial purposes and have been listed as priority pollutants by agencies such as U.S. Environmental Protection Agency [1]. Humans are regularly exposed to PAEs through food, medicines, plastics, dairy products, cosmetics, etc. PAEs and their metabolites have been reported to cause reproductive and developmental disorders. PAEs have also been reported to be hepatotoxic, teratogenic and carcinogenic [2]. PAEs are not tightly bonded to the polymers (such as plastics), hence leach out into the environment and pose serious risks to ecosystem components.

DMP is used in cellulose ester based plastics, paints, adhesives, printing inks and coatings. Due to its wide applications in industries, DMP has been recognized as a significant environmental contaminant. DMP is a relatively stable compound in the natural environment with a half life of $\approx 20$ years [3]. DMP promotes chromosomal injuries in human leucocytes, also known to be an endocrine disrupting

Manuscript received February 10, 2012, revised February 28,2012.

B. Prasad and S. Suresh are with the Centre for Environmental Science and Engineering (CESE) at the Indian Institute of Technology Bombay (IITB), Powai, Mumbai, India. (e-mails: sumathis@iitb.ac.in; bablup@iitb.ac.in) chemical (EDC) that interferes with the reproductive system and normal development of animals and humans [4]. DEP is used as a solvent vehicle for fragrance and in cellulose ester based plastics. DEP has been reported to cause abnormality in sexual differentiation and also act as an endocrine disrupting chemical [5], [6]. DBP is used in cosmetics, children's toys and child care products. DBP has been reported to reduce human sperm production and its motility, decrease rates of pregnancy and promote miscarriages [2], [7], [8].

Removal and degradation of PAEs by abiotic processes such as hydrolysis and photodecomposition has been reported to be slow and insignificant. However, breakdown by microorganisms is considered to be one of the major routes of environmental degradation for these widespread pollutants [9]. Number of investigators has demonstrated successful degradation of several PAEs by microbes under aerobic conditions in soil, water and wastewater [10]. Although there are number of reports on the biodegradation of individual PAEs, there is scanty literature available on degradation of mixture of PAEs. Industrial wastes frequently contain mixture of PAEs and therefore it is important to investigate the biodegradation of their mixtures rather than individual PAEs. The goal of present investigation was to demonstrate biodegradation of individual phthalate esters and their mixture using whole cells of a newly isolated bacterial strain as well as cell free crude enzyme preparations from the isolate.

\section{ATERIALS AND METHODS}

\section{A. Chemicals}

Dimethyl phthalate, diethyl phthalate and dibutyl phthalate were procured from Sigma-Aldrich, USA. HPLC grade methanol and acetonitrile were purchased from Merck India Limited, Mumbai. All chemicals were of high purity (>99\%). All experiments were performed in duplicate unless otherwise specified.

\section{B. Isolation of PAE Degrading Bacterial Strain and Culture Conditions}

Microorganisms capable of utilizing the three phthalate esters as a mixture (DMP, DEP and DBP) were isolated via enrichment culture technique. Samples were taken from soil contaminated with electronic and plastic wastes situated near Powai Lake, Indian Institute of Technology Bombay (IITB). The initial enrichment culture was started by inoculating 100 $\mathrm{ml}$ of sterile mineral salts medium (MSM) with $1 \mathrm{~g}$ of fresh soil sample and $100 \mathrm{mg} / \mathrm{l}$ each of DMP, DEP and DBP in a $250 \mathrm{ml}$ Erlenmeyer flask. The MSM consisted of: $3.5 \mathrm{~g}$ 
$\mathrm{K}_{2} \mathrm{HPO}_{4}, 1.5 \mathrm{~g} \mathrm{KH}_{2} \mathrm{PO}_{4}, 0.27 \mathrm{~g} \mathrm{MgSO}_{4}, 1 \mathrm{~g} \mathrm{NH}{ }_{4} \mathrm{Cl}, 0.03 \mathrm{~g}$ $\mathrm{Fe}_{2}\left(\mathrm{SO}_{4}\right)_{3} 7 \mathrm{H}_{2} \mathrm{O}$ and $0.03 \mathrm{~g}$ of $\mathrm{CaCl}_{2}$ dissolved in 11 of water [11]. The $\mathrm{pH}$ of MSM was adjusted to $\sim 6.8$ and sterilized by autoclaving. Iron sulphate and magnesium sulphate were filter-sterilized and added from respective stock solutions to the cooled sterile medium. No other source of carbon other than phthalate esters was added. Inoculated flasks were incubated on an orbital rotary incubator shaker maintained at $180 \mathrm{RPM}$ and $30^{\circ} \mathrm{C}$. The cell growth was monitored by visual inspection. PAE degrading microbial population was obtained following five successive enrichments which involved repeated transfer of $1 \mathrm{ml}$ of culture into fresh MSM containing mixture of PAEs. This was to ensure the elimination of growth supportive constituents contributed from soil and to gradually enrich biodegrader population capable of utilizing PAEs as their sole source of carbon and energy. Finally a single bacterial colony which had the ability to grow rapidly on agar plates containing mixture of PAEs (100 mg/l each of DMP, DEP and DBP) was selected, grown in MSM for $24 \mathrm{~h}$ culture, pelleted at $4^{\circ} \mathrm{C}$ and analysed for $16 \mathrm{~S}$ r-DNA sequence. The pure culture of bacterial strain was also subjected to wet mounting, Gram staining and observed under oil immersion lens using the Zeiss phase contrast microscope.

\section{16S r-DNA Sequencing for the Identification of Isolated Bacterial Strain}

16S r-DNA analysis was performed by Bangalore Genei, India. Genomic DNA was isolated from the pure culture pellet. Primers were designed based on conserved regions of bacterial 16S r-DNA sequence. Using consensus primers, $\sim 1.5 \mathrm{~kb}$ r-DNA fragment was amplified using high-fidelity Xt5 polymerase (a combination of Taq and Pfu polymerase). The PCR product was bi-directionally sequenced using the forward, reverse and an internal primer. $16 \mathrm{~S}$ r-DNA sequence data was aligned and analyzed for identifying the closest homology for the isolated bacterial strain. Phylogenetic tree was constructed in MEGA 3.1 software using neighbour joining method to analyze the relationship between the isolated bacterial strain BS1 with the other species from neighboring taxa.

\section{Growth Profiles of the Isolated Bacterial Culture}

Overnight grown starter culture (O.D. of 0.4) of the isolated bacterial strain was inoculated into $150 \mathrm{ml}$ of fresh MSM containing $300 \mathrm{mg} / \mathrm{l}$ of DMP or DEP or DBP or a mixture containing all the three PAEs $(100 \mathrm{mg} / \mathrm{l}$ of each) and incubated at $30^{\circ} \mathrm{C}$ on a rotary shaker $(180 \mathrm{RPM})$. Five $\mathrm{ml}$ aliquots of the culture medium were withdrawn at regular intervals of time to record the cell optical density values at $600 \mathrm{~nm}$. Plots of $\ln \left(\mathrm{X}_{\mathrm{t}} / \mathrm{X}_{0}\right)$ versus time were used to calculate specific growth rates $(\mu)$ on individual PAEs and their mixture. $X_{t}$ and $X_{0}$ represent the absorbance values at $600 \mathrm{~nm}$ at time $\mathrm{t}$ and zero, respectively.

\section{E. Biodegradation of DMP, DEP, DBP and Their Mixture}

The conditions for the cultivation of bacterial strain were similar to those described under section D. Following addition of $1.5 \mathrm{ml}$ of overnight grown starter culture (O. D. of 0.4 ), aliquots of the spent growth medium containing DMP or DEP were aliquoted at chosen time points, centrifuged at
$11,000 \mathrm{RPM}$ for $15 \mathrm{~min}$ at $25^{\circ} \mathrm{C}$ to separate cells and the clear cell free supernatant was subjected to HPLC analyses. An equal volume of methanol was added into the spent growth medium which contained DBP or mixture of PAEs and mixed vigorously for $1 \mathrm{~min}$ to aid complete solubilization of DBP in the aqueous phase. Thereafter the cells were pelleted and discarded while the clarified supernatant was subjected to HPLC analyses. A control flask with un-inoculated growth medium was also maintained under same conditions on the test flasks and analyzed for the abiotic loss of PAEs.

\section{F. Preparation of Cell-Free Extracts}

The method of Prathibha and Suresh was used with some modifications [12]. Bacterial cells grown on phthalate esters were harvested at mid exponential phase $(\sim 17 \mathrm{~h})$ by centrifugation at $4{ }^{\circ} \mathrm{C}$. The cell pellet was washed twice using $20 \mathrm{mM}$ sodium phosphate buffer ( $\mathrm{pH}$ 7.0) and subsequently resuspended in three volumes of the same buffer containing $20 \mathrm{mM}$ 2-mercaptoethanol and $10 \%$ glycerol. The cell suspension was maintained at 0 to $4^{\circ} \mathrm{C}$ and subjected to pulse mode ultra-sonic cell disruption at 50 duty cycle for 7 minutes using a Branson sonifier. Sonicated cell suspension was then centrifuged at 11,000 RPM for 45 minutes at $4^{\circ} \mathrm{C}$. The clear cell free supernatant was designated as the crude cell free extract.

\section{G. Assay of Enzyme Activities Using Cell Free Crude Extracts}

\section{1) Esterase assay using p-nitrophenyl acetate as the substrate}

Esterase activity was determined using $p$-nitrophenyl acetate (pNPA) as the substrate. The method of Xu et al., was used with some modifications [13]. The test reaction mixture $(1 \mathrm{ml})$ consisted of freshly prepared $0.064 \mathrm{mM}$ of pNPA $(0.2$ $\mathrm{ml}$ added from a stock solution prepared in methanol), $0.2 \mathrm{ml}$ of $50 \mathrm{mM}$ potassium phosphate buffer ( $\mathrm{pH} 7.0), 0.1 \mathrm{ml}$ of cell free extract (protein concentration of $\sim 2 \mathrm{mg} / \mathrm{ml}$ ), and $0.5 \mathrm{ml}$ of distilled water. was incubated in a water bath maintained at $30^{\circ} \mathrm{C}$ for $3 \mathrm{~min}$. Absorbance was recorded at $400 \mathrm{~nm}$ which is the $\lambda_{\max }$ of the product, $p$-nitrophenol. The control reaction mixture consisted of all the components present in the test reaction mixture except that the cell free extract was omitted and corresponding volume of plain phosphate buffer was added. An additional control reaction mixture consisted of all the components of test reaction mixture and denatured (prior incubation at $100^{\circ} \mathrm{C}$ for $5 \mathrm{~min}$ ) cell free extract. One unit of enzyme activity was defined as the amount of protein required to form 1 nmole of the end product, $p$-nitrophenol per min and specific enzyme activity was defined as nmoles of $p$-nitrophenol formed per min per $\mathrm{mg}$ of protein. Calibration plots for the desired range of concentrations of p-nitrophenol were obtained.

\section{2) Enzyme Activity Using DMP or DEP as the Substrates}

The test reaction mixture $(10 \mathrm{ml})$ consisted of $1 \mathrm{mM}$ of DMP or DEP and $3 \mathrm{ml}$ of crude cell free extract (protein concentration of $\sim 2 \mathrm{mg} / \mathrm{ml}$ ) in $20 \mathrm{mM}$ sodium phosphate buffer ( $\mathrm{pH}$ 6.8). Protein concentrations in cell free extracts were measured using Bradford's method [14]. The control reaction mixture consisted of all the components present in the test reaction mixture except that the cell free extract was omitted and corresponding volume of plain phosphate buffer 
was added. An additional control reaction mixture consisted of all the components of test reaction mixture and denatured (prior incubation at $100^{\circ} \mathrm{C}$ for $5 \mathrm{~min}$ ) cell free extract. The tubes containing reactions mixtures were incubated in a water bath shaker for one hour at $30^{\circ} \mathrm{C}$. Aliquots of the reaction mixtures were withdrawn at regular intervals of time, acidified using acid $(2 \mathrm{~N} \mathrm{HCl})$ to terminate the reaction and centrifuged to remove the precipitated protein. The clarified supernatant was further filtered through $0.2 \mu \mathrm{m}$ nylon membrane and subjected to HPLC analyses. One unit (U) of enzyme was defined as the amount of protein that was able to catalyze the removal of $1 \mathrm{nmol}$ of target PAE per minute. Specific activity of cell free crude extract was calculated as the number of enzyme units per mg of protein.

\section{H. Determination of Thermostability of Cell Free Extracts as a Function of Storage Time and Temperature}

Enzyme assays were performed to examine the stability of esterase in cell free extracts using DMP or $p$-nitrophenyl acetate as the substrates. The protocols used for enzymatic assays were similar to those described in the previous sections (G-1 and G-2). A portion of the freshly prepared cell free extracts was assayed immediately for the enzyme activity (day 0). The remaining cell free extract was dispensed into 18 sample tubes closed tightly and divided into three groups. One group was stored at room temperature (approximately $25^{\circ} \mathrm{C}$ ) while the other two groups were stored at $4^{\circ} \mathrm{C}$ and $-20^{\circ} \mathrm{C}$. Aliquoted extracts stored at three different temperatures were assayed for residual enzymatic activities as a function of storage time (for example at 1, 2, 4, 6, 8 and $10 \mathrm{~d}$ ). Aliquots of the stored crude extract were allowed to pre-equilibrate for a short time to attain room temperature and mixed well prior to assays at the designated time points.

\section{Effect of Glycerol Concentrations on Esterase Activity}

Cell free extracts were prepared from the isolated bacterial strain using extraction buffer containing 1,5 or $10 \%$ of glycerol. Esterase activity in the cell free extracts solution was measured using DMP as the substrate. The method used for this enzyme assay was according to the protocol described under section G-2.

\section{J. Analytical Methods}

Phthalate esters were analyzed using Schimadzu HPLC, equipped with a high pressure pump (LC-20AD), degasser (DGU-20A 5 ), photo diode array detector (PDA) (SPD-M20A) and an auto sampler (SIL-20AHT). A kromasil C18 column ( $5 \mu \mathrm{m}$ particle size, $250 \mathrm{~mm} \times 4.6 \mathrm{~mm}$ i.d.) was used with a mobile phase consisting of methanol/water $(80: 20, \mathrm{v} / \mathrm{v})$ at a flow rate of $1 \mathrm{ml} / \mathrm{min}$. Sample injection volume was $10 \mu \mathrm{l}$. Calibration plots for the desired range of concentrations of individual phthalate esters were obtained.

\section{RESUlTS AND DisCUSSION}

\section{A. Isolation and Characterization of PAEs Degrading Strain}

Microscopic examination revealed that the isolated bacterial strain was motile, rod shaped and Gram-negative. Colonies produced on MSM agar plates containing PAEs (as the sole source of carbon and energy) were pale white and smooth. The partial 16S r-DNA sequence alignment from the isolated strain, BS1 revealed that it was most closely related to Variovorax sp. (GenBank Accession Number AB513921) with complete homology ( $100 \%$ similarity based on $\approx 15 \mathrm{~kb})$. The next closest homolog was Variovorax paradoxus (GenBank Accession Number DQ335121) with $99.8 \%$ similarity. Figure 1 illustrates the phylogenetic relationship of strain BS1 based on $16 \mathrm{~S}$ r-DNA sequence alignments.Variovorax species are known to be widespread in nature and have been reported to degrade dimethyl terephthalate [15], phenol, trichloroethylene [16], 2, 2' dithiodibenzoic acid [17], 2, 4 dichlorophenoxy acetate [18] and phenylurea herbicide diuron [19].

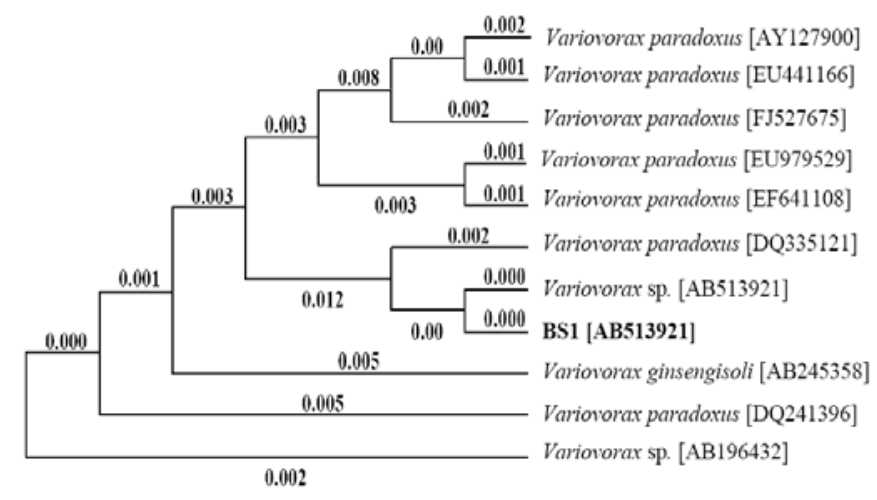

Fig. 1. Phylogenetic tree based on the $16 \mathrm{~S}$ r-DNA sequence alignments showing the relationship of PAEs degrading bacterial isolate, Variovorax sp. strain BS1 (indicated in a bold letter) to other Variovorax species and sequences of bacteria from neighboring taxa. Sequence was aligned using Kimura 2 parameter method. The tree was constructed using neighbour joining method

\section{B. Bacterial Growth on PAEs and Biodegradation of DMP, DEP, DBP and Their Mixture}

The isolated bacterial strain, identified as Variovorax sp. was able to utilize DMP, DEP, DBP or their mixture as the sole sources of carbon and energy. Figure 2 demonstrates the time dependent reduction in the concentrations of DMP (a), DEP (b), DBP (c) and their mixtures (d) with the concomitant increase in the cell density of Variovorax species. The control flasks (without bacteria) did not show significant changes in the concentrations of PAEs which indicated negligible abiotic loss of the phthalate esters. The specific growth rates $(\mu)$ of Variovorax sp. in $300 \mathrm{mg} / \mathrm{l}$ of DMP, DEP, DBP and a mixture containing $100 \mathrm{mg} / \mathrm{l}$ of each phthalate ester were computed to be 0.085 per $h, 0.107$ per h, 0.087 per $h$ and 0.077 per h, respectively. 

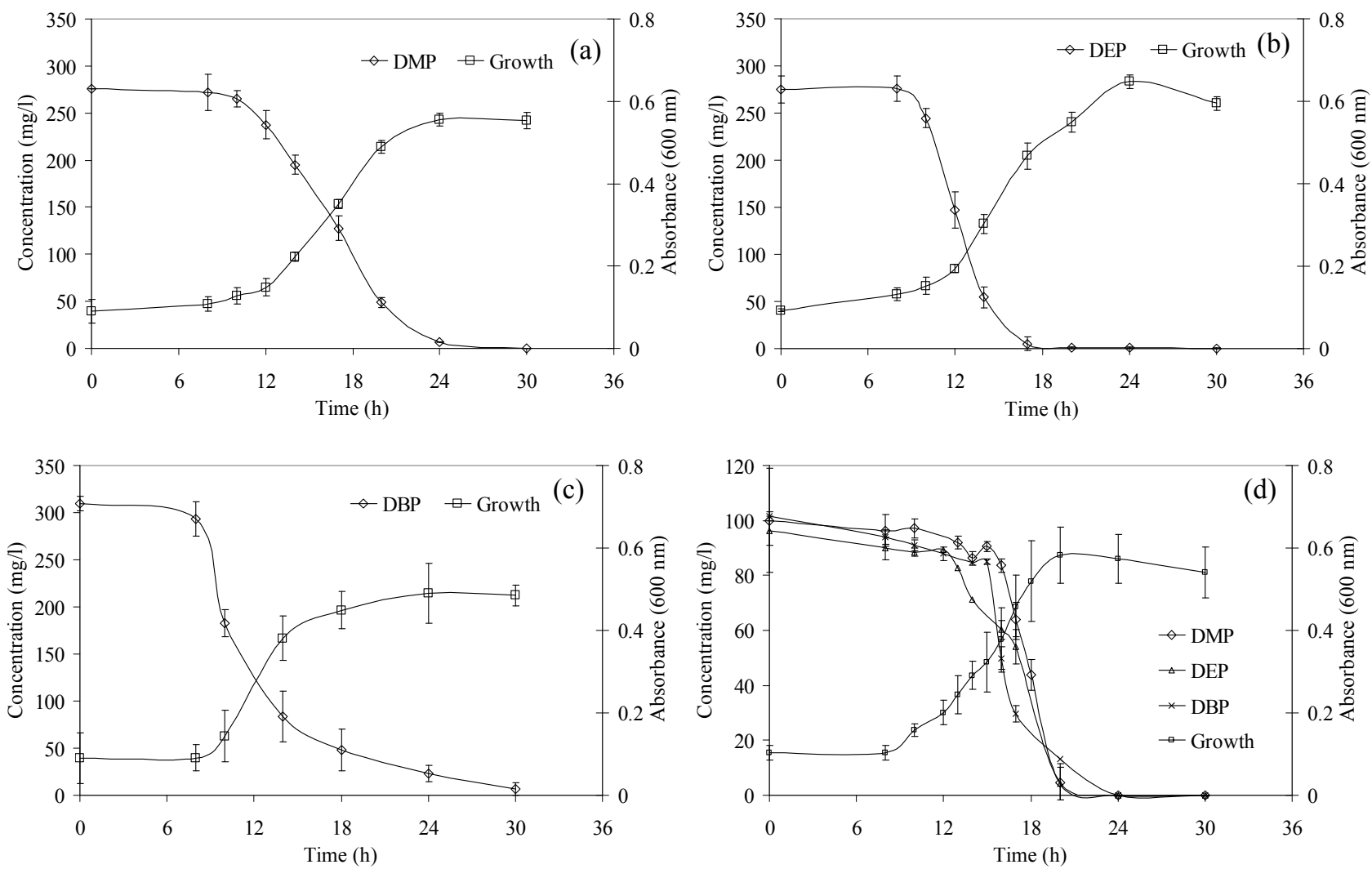

Fig. 2. Time course profiles for the removal of $300 \mathrm{mg} \mathrm{L}^{-1}$ of (a) DMP; (b) DEP; (c) DBP; (d) mixture containing $100 \mathrm{mg} \mathrm{L}^{-1}$ of each by Variovorax sp. and corresponding growth profiles

TABLE I: Rate Constants and Half Lives of Phthalate Esters Based on the First ORder Biodegradation Kinetic Plots ObTained Using WHOLE CELLS OF VARIOVORAX sp.

\begin{tabular}{|c|c|c|c|c|}
\hline PAEs used in the growth medium & PAEs monitored & First order rate constant (per h) & Half life (h) & $\frac{\mathrm{R}^{2}}{}$ \\
\hline DMP alone $(300 \mathrm{mg} / \mathrm{l})$ & DMP & 0.3 & 2.4 & 0.85 \\
\hline DEP alone (300 mg/l) & DEP & 0.44 & 1.6 & 0.87 \\
\hline DBP alone (300 mg/l) & DBP & 0.36 & 1.9 & 0.97 \\
\hline $\begin{array}{l}\text { Mixture of DMP + DEP + DBP } \\
(100 \mathrm{mg} / \mathrm{l} \mathrm{each})\end{array}$ & DMP & 0.27 & 2.6 & 0.94 \\
\hline $\begin{array}{l}\text { Mixture of DMP + DEP + DBP } \\
(100 \mathrm{mg} / \mathrm{l} \mathrm{each})\end{array}$ & DEP & 0.34 & 2.1 & 0.96 \\
\hline $\begin{array}{l}\text { Mixture of DMP + DEP + DBP } \\
(100 \mathrm{mg} / \mathrm{l} \text { each })\end{array}$ & DBP & 0.24 & 2.8 & 0.93 \\
\hline
\end{tabular}

Biodegradation of DMP, DEP, DBP and their mixture containing all the three PAEs followed first-order kinetics corresponding to the equation: $\mathrm{dC} / \mathrm{dt}=-\mathrm{kC}$ where $\mathrm{C}$ and $\mathrm{k}$ represent residual concentration of the target $\mathrm{PAE}$ at any time $\mathrm{t}$ and degradation rate constant, respectively. Results presented in Table I suggest that the rates of degradation of individual PAEs followed the order: $\mathrm{DEP}>\mathrm{DBP}>\mathrm{DMP}$ while in the mixture the order was: $\mathrm{DEP}>\mathrm{DMP}>\mathrm{DBP}$. However in the current investigations, extra-cellular accumulation of metabolites or end product could not be detected at any time point by HPLC analyses.

\section{Biodegradation of DMP and DEP Using Cell Free Crude Extracts}

Fig. 3 demonstrates time dependent biodegradation of 1 $\mathrm{mM}$ of DMP and DEP by cell free extracts derived from
Variovorax sp. The extent of biodegradation of DMP and DEP were $\sim 82 \%$ and $\sim 90 \%$, respectively after 60 min of incubation. HPLC profiles did not reveal the presence of intermediates or products. These results suggested that the cell free crude extracts derived from Variovorax $\mathrm{sp}$. contained the necessary cocktail of enzymes for the biodegradation of DMP or DEP. Specific activities of DMP esterase and DEP esterase were $\sim 89 \mathrm{nmole} / \mathrm{min} / \mathrm{mg}$ and 170 nmole/min/mg, respectively, using $1 \mathrm{mM}$ DMP or DEP. Removal of DMP or DEP was insignificant in control experiments wherein denatured cell free extracts were used. These results indicated that the abiotic loss of PAEs was negligible under the experimental conditions used in this investigation. 


\section{D.Stability of Esterase Enzyme as a Function of Storage} Temperature and Time

Table II shows esterase activities as a function of storage temperature and time using DMP and p-nitrophenyl acetate as substrates. DMP esterase showed highest activity in freshly prepared cell free extracts. However the enzyme was rapidly inactivated by incubation at $25^{\circ} \mathrm{C}$. At $-20^{\circ} \mathrm{C}$, the enzyme showed $\sim 25 \%$ and $\sim 50 \%$ reduction in the activity after $2 \mathrm{~d}$ and $10 \mathrm{~d}$ of incubation, respectively. A similar trend was also observed using $p$ NPA as the substrate (last column of Table 2). These results revealed that the storage time and temperature had significant effect on the enzyme activity. DMP and $p$ NPA esterase activities were not stable and hence the crude cell free extracts could not be stored for a long time period. However, the protective effects of substrate and ammonium sulfate fractionation need to be investigated further.

\section{E.Induction of Esterase Enzyme}

One of the most crucial aspects of environmental adaptation is the role of substrates in the induction and maintenance of biodegradative enzyme activities in bacterial cells. In order to correlate the involvement of phthalate ester such as DMP in the induction of corresponding esterase, cell free extracts were prepared from Variovorax cells grown on three different types of carbon sources, namely, DMP (600 $\mathrm{mg} / \mathrm{l})$ or phthalic acid $(641 \mathrm{mg} / \mathrm{l})$ or glucose $(927 \mathrm{mg} / \mathrm{l})$. The concentrations of the three substrates were adjusted to achieve elemental carbon equivalence. Fig. 4 suggests that the specific activity of the esterase using DMP as the substrate was $\sim 33$ and $\sim 16$ times higher as compared to those observed using glucose and phthalic acid, respectively. Similarly, esterase activity measured using $p$ NPA as the substrate was $\sim 10$ and $\sim 6$ times higher as compared to those observed using glucose and phthalic acid, respectively. These results demonstrated that the DMP degrading enzyme was significantly induced by the presence of DMP, its target substrate which was being used as the sole source of carbon and energy by the isolated bacterial strain. Activation and expression of specific biodegradative genes which in turn leads to the synthesis of inducible enzymes in the presence of environmental pollutants is a well known phenomenon [20].

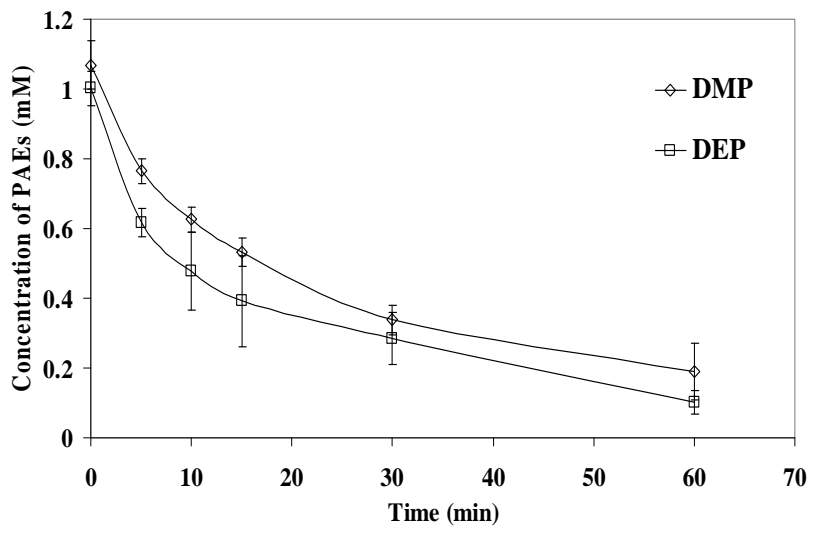

Fig. 3. Time course profiles for the degradation of $1 \mathrm{mM}$ DMP or DEP using cell free extracts derived from Variovorax sp.

\section{F. Effect of Glycerol Concentration on Esterase Activity}

DMP esterase showed highest activity ( $89 \mathrm{nmole} / \mathrm{min} / \mathrm{mg}$ ) in cell free extracts containing $10 \%$ glycerol. Inclusion of lower glycerol concentrations in the crude enzyme extracts led to substantial reduction in the enzyme activity. As an example, the specific activity of DMP esterase was 52 $\mathrm{nmole} / \mathrm{min} / \mathrm{mg}$ in $5 \%$ glycerol and 23 nomle/min $/ \mathrm{mg}$ in $1 \%$ glycerol. These results indicated that the presence of glycerol facilitated in stabilizing the native 3-dimensional structure of protein and hence the functional integrity of catalytic (active) site of the enzymes involved.

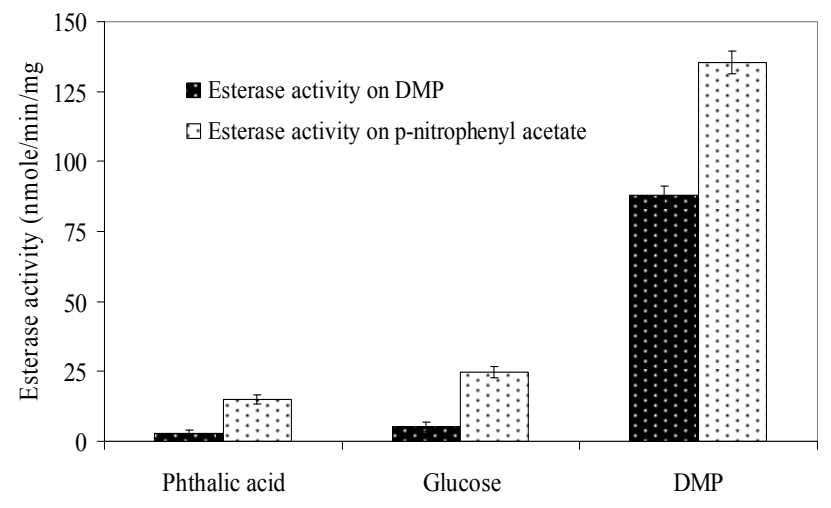

Fig. 4. Comparison of esterase activities in cell free extracts obtained from Variovorax sp. grown on phthalic acid or glucose or DMP.

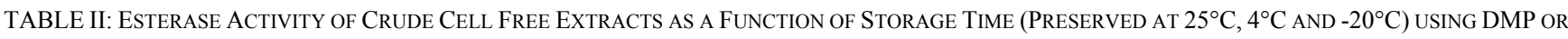
P-NitROPHENYL ACETATE AS THE SUBSTRATES

\begin{tabular}{|c|c|c|c|c|c|c|}
\hline \multirow{3}{*}{$\begin{array}{l}\text { Time of } \\
\text { storage (d) }\end{array}$} & \multicolumn{3}{|c|}{ Esterase activity using DMP (nmole/min/mg) } & \multicolumn{3}{|c|}{ Esterase activity using $p$-nitrophenyl acetate (nmole $/ \mathrm{min} / \mathrm{mg}$ ) } \\
\hline & \multicolumn{6}{|c|}{ Storage temperature } \\
\hline & $25^{\circ} \mathrm{C}$ & $4^{\circ} \mathrm{C}$ & $-20^{\circ} \mathrm{C}$ & $25^{\circ} \mathrm{C}$ & $4^{\circ} \mathrm{C}$ & $-20^{\circ} \mathrm{C}$ \\
\hline 0 & 88.8 & 88.8 & 88.8 & 132.7 & 132.7 & 132.7 \\
\hline 1 & 36.6 & 46.3 & 75.5 & 47.4 & 66.2 & 113.1 \\
\hline 2 & 33.1 & 41.8 & 67.1 & 41.4 & 60.5 & 98 \\
\hline 4 & 33.1 & 36.6 & 54.8 & 42.7 & 47.9 & 92.3 \\
\hline 6 & 32.1 & 34.4 & 49.3 & 35 & 44.2 & 87.3 \\
\hline 8 & 28.8 & 31.8 & 45.4 & 37.5 & 46.9 & 78.9 \\
\hline 10 & 26.9 & 27.5 & 47 & 33.2 & 47.6 & 69.2 \\
\hline
\end{tabular}




\section{CONCLUSION}

The newly isolated bacterial strain, Variovorax sp. had the ability to utilize DMP, DEP, and DBP individually or as a mixture using them as the sole source of carbon and energy. The bacterial strain was able to degrade $>99 \%$ of $300 \mathrm{mg} \mathrm{L}^{-1}$ PAEs in $30 \mathrm{~h}$. The rates of biodegradation of PAEs by Variovorax were higher as compared to those reported in the literature using other species of bacteria. Accumulation of metabolites or end products from the degradation of PAEs was not observed in the present investigations. This observation is in contrast to those reported in the literature which suggested the production of toxic metabolites (such as monomethyl phthalate or monoethyl phthalate) during biodegradation of PAEs. Results related to degradation of DMP or DEP using cell free extracts from Variovorax species suggested that the enzymes were inducible and efficient in the biodegradation of phthalate esters. Variovorax sp. was capable of degrading mixture of PAEs and therefore the isolate may be applied for field scale bioremediation.

\section{ACKNOWLEDGMENT}

The authors thank Indian Institute of Technology Bombay for providing the necessary infrastructure and CSIR (Council for Scientific and Industrial Research, Government of India) for providing fellowship to the Ph.D. candidate.

\section{REFERENCES}

[1] J. X. Li, J. D. Gu, and L. Pan, "Transformation of dimethyl phthalate, dimethyl isophthalate and dimethyl terephthalate by Rhodococcus rubber Sa and modeling the processes using the modified Gompertz model," Int Biodeterior Biodegrad, vol. 55, pp. 223-232, 2005.

[2] M. Matsumoto, K. M. Hirata, and M. Ema, 'Potential adverse effects of phthalic acid esters on human health: a review of recent studies on reproduction," Regul Toxicol Pharm, vol. 50, pp. 37-49, 2008.

[3] C. A. Staples, D. R. Peterson, T. F. Parkerton, and W.J. Adams, "The environmental fate of phthalate esters: a literature review," Chemosphere, vol. 35, pp. 667-749, 1997.

[4] B. L. Yuan, X. Z. Li, and N. Graham, "Reaction pathways of dimethyl phthalate degradation in $\mathrm{TiO}_{2}-\mathrm{UV}-\mathrm{O}_{2}$ and $\mathrm{TiO}_{2}-\mathrm{UV}-\mathrm{Fe}(\mathrm{VI})$ systems," Chemosphere, vol. 72, pp. 197-204, 2008.

[5] J. L. E. Gray, J. Ostby, J. Furr, M. Price, D. N. Veeramachaneni, L. Parks, "Perinatal exposure to the phthalates DEHP, BBP, and DINP, but not DEP, DMP, or DOTP, alters sexual differentiation of the male rat," Toxicol Sci, vol. 58, pp. 350-365, 2000.

[6] B. V. Chang, T.H. Wang, and S. Y. Yuan, "Biodegradation of four phthalate esters in sludge," Chemosphere, vol. 69, pp. 1116-1123, 2007.

[7] D. A. Murature, S. Y. Tang, G. Steinhardt, and R. C. Dougherty, "Phthalate esters and semen quality parameters," Biomed Environ Sci, vol. 14, pp. 473-477, 1987.

[8] B. Fredricsson, L. Moller, A. Pousette, and R. Westerholm, "Human sperm motility is affected by plasticizers and diesel particle extracts," Pharmacol Toxicol, vol. 72, pp. 128-133, 1993.

[9] Y. Lu, F. Tang, Y. Wang, J. Zhao, X. Zeng, Q. Luo, and L. Wang, "Biodegradation of dimethyl phthalate, diethyl phthalate and dibutyl phthalate by Rhodococcus sp. L4 isolated from activated sludge," $J$ Hazard Mater, vol. 168, pp. 938-943, 2009.
[10] B. V. Chang, C. M. Yang, C.H. Cheng, and S. Y. Yuan, "Biodegradation of phthalate esters by two bacterial strains," Chemosphere, vol. 55 pp. 533-538, 2004.

[11] D. Vega, and J. Bastide, "Dimethylphthalate hydrolysis by specific microbial esterase," Chemosphere, vol. 51, pp. 663-668, 2003.

[12] K. Prathibha, and S. Sumathi, "Biodegradation of mixture containing monohydroxybenzoate isomers by Acinetobacter calcoaceticus," World J Microbial Biotechnol, vol. 24, pp. 813-823, 2008.

[13] S. Xu, C. Komatsu, I. Takahashi, and S. Suye, "Purification and properties of diethyl p-phthalate esters from Ochrobactrum anthoropi 6-2b," SEN'I GAKKAISHI, vol. 62 (10), pp. 226-231, 2006.

[14] M. M. Bradford, "A rapid and sensitive method for the quantitation of microgram quantities of protein utilizing the principle of protein-dye binding," Analytical Biochemistry, vol. 72, pp. 248-254, 1976.

[15] Y. P. Wang, and J. D. Gu, "Degradability of dimethyl terephthalate by Variovorax paradoxus T4 and Sphingomonas yanoikuyae DOS01 isolated from deep-ocean sediments," Ecotoxicol, vol. 15 pp. 549-557, 2006.

[16] H. Futamata, Y. Nagano, K. Watanabe, and A. Hiraishi, "Unique kinetic properties of phenol-degrading Variovorax strains responsible for efficient trichloroethylene degradation in a chemostat enrichment culture," Appl Environ Microbiol, vol. 71(2) pp. 904-911, 2005.

[17] R. F. Young, S. M. Cheng, and P. M. Fedorak, "Aerobic biodegradation of 2,2-dithiodibenzoic acid produced from dibenzothiophene metabolites, Appl Environ Microbiol, vol. 72(1) pp. 491-496, 2006.

[18] A. Kei, S. Mitsuhiro, H. Takayuki, K. Mitsuyasu, "Biodegradation of 2, 4- dichlorophenoxy acetate by novel isolated bacteria," Report of Electronic Research Laboratory, Fukuoka Institute of Technology, vol. 21, pp. 23-28, 2004

[19] S. R. Sorensen, C. N. Albers, and J. Aamand, "Rapid mineralization of the phenylurea herbicide diuron by Variovorax sp. strain SRS16 in pure culture and within a two-member consortium," Appl Environ Microbiol, vol. 74(8), pp. 2332-2340, 2008.

[20] B. D. Ensley, and M. F. DeFlaun, "Hazardous chemicals and biotechnology: past success and future promise" in: Microbial Transformation and Degradation of Toxic Organic Chemicals (Eds: L. Y. Young, and C. E. Cerniglia), 605 Third Avenue, New York, USA: Wiley-Liss, Inc., 1995, ch. 17, pp. 603-629

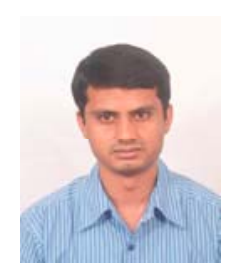

Bablu Prasad was born in Daltonganj, India on $8^{\text {th }}$ December 1983. He receive his bachelor of science degree in chemistry from Ranchi University, Ranchi, Jharkhand, India in 2005, the master of science degree in Biotechnology from Annamalai University, Chidambaram, Tamil Nadu, India in 2008. Currently, he is a senior Ph.D. student at the Centre for Environmental Science and Engineering (CESE), Indian Institute of Technology Bombay (IITB), Powai, Mumbai 400076, India. His research interests include microbial remediation of environmental pollutants and application of molecular biology tools for environmental studies.

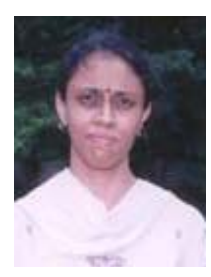

Sumathi Suresh is a full time professor at the Centre for Environmental Science and Engineering (CESE), Indian Institute of Technology Bombay (IITB), Powai, Mumbai 400076, India. She holds a Ph.D. degree in the field of biochemistry (enzymology) from Indian Institute of Science, Bangalore, India. She has published 50 international papers, 3 book chapters and holds national and international patents. She is the editorial board member of several reputed international journals. Her research interests include chemical and biological remediation of environmental pollutants, biomonitoring of contaminants and pathogens in water and application of molecular biological tools for studying microbial diversity in biological reactors. 